\title{
Contribution of pulmonary function tests (PFTs) to the diagnosis and follow up of connective tissue diseases
}

\author{
Nicola Ciancio ${ }^{1,2^{*}}$ (D, Mauro Pavone ${ }^{1}$, Sebastiano Emanuele Torrisi ${ }^{1}$, Ada Vancheri ${ }^{1}$, Domenico Sambataro ${ }^{3}$, \\ Stefano Palmucci ${ }^{4} \mathbb{D}$, Carlo Vancheri ${ }^{1} \mathbb{D}$, Fabiano Di Marco ${ }^{5}$ and Gianluca Sambataro ${ }^{1,3}$ (B)
}

\begin{abstract}
Introduction: Connective Tissue Diseases (CTDs) are systemic autoimmune conditions characterized by frequent lung involvement. This usually takes the form of Interstitial Lung Disease (ILD), but Obstructive Lung Disease (OLD) and Pulmonary Artery Hypertension (PAH) can also occur. Lung involvement is often severe, representing the first cause of death in CTD. The aim of this study is to highlight the role of Pulmonary Function Tests (PFTs) in the diagnosis and follow up of CTD patients.

Main body: Rheumatoid Arthritis (RA) showed mainly an ILD with a Usual Interstitial Pneumonia (UIP) pattern in High-Resolution Chest Tomography (HRCT). PFTs are able to highlight a RA-ILD before its clinical onset and to drive follow up of patients with Forced Vital Capacity (FVC) and Carbon Monoxide Diffusing Capacity ( $\mathrm{DL}_{\mathrm{CO}}$ ). In the course of Scleroderma Spectrum Disorders (SSDs) and Idiopathic Inflammatory Myopathies (IIMs), DL be more sensitive than FVC in highlighting an ILD, but it can be compromised by the presence of PAH. A restrictive respiratory pattern can be present in IIMs and Systemic Lupus Erythematosus due to the inflammatory involvement of respiratory muscles, the presence of fatigue or diaphragm distress.

Conclusions: The lung should be carefully studied during CTDs. PFTs can represent an important prognostic tool for diagnosis and follow up of RA-ILD, but, on their own, lack sufficient specificity or sensitivity to describe lung involvement in SSDs and IIMs. Several composite indexes potentially able to describe the evolution of lung damage and response to treatment in SSDs are under investigation. Considering the potential severity of these conditions, an HRCT jointly with PFTs should be performed in all new diagnoses of SSDs and IIMs. Moreover, follow up PFTs should be interpreted in the light of the risk factor for respiratory disease related to each disease.
\end{abstract}

Keywords: Interstitial lung disease, Rheumatoid arthritis, Connective tissue disease, Antisynthetase Syndrome, Systemic sclerosis, Sjögren Syndrome, Dermatomyositis, Polymyositis, Mixed connective tissue disease, Interstitial pneumonia with autoimmune features

\section{Background}

Connective Tissue Diseases (CTDs) are often characterized by pulmonary involvement. The main clinical presentation is Interstitial Lung Disease (ILD), characterized by an involvement of the lung interstitium with inflammatory

\footnotetext{
*Correspondence: ciancio@policlinico.unict.it

${ }^{1}$ Regional Referral Center for Rare Lung Diseases, A. O. U. "Policlinico-Vittorio Emanuele" Department of Clinical and Experimental Medicine, University of Catania, Catania, Italy

${ }^{2}$ Respiratory Physiopathology Group. Società Italiana di Pneumologia. Italian Respiratory Society (SIP/IRS), Milan, Italy

Full list of author information is available at the end of the article
}

cells and/or exaggerated deposition of extracellular matrix by myofibroblasts. Pulmonary Artery Hypertension (PAH, a potentially lethal condition characterized by high blood pressure in lung arteries) and Obstructive Lung Diseases (OLDs, an airway obstruction with airflow limitation) can also occur. These three conditions, with several pathogenic pathways directly or indirectly related to CTDs can be present alone or in combination. The lung disease can be severe, and often represents the main cause of death for these patients [1]. Currently, Pulmonary Function Tests (PFTs) in clinical practice appear to be confined to

(c) The Author(s). 2019 Open Access This article is distributed under the terms of the Creative Commons Attribution 4.0 International License (http://creativecommons.org/licenses/by/4.0/), which permits unrestricted use, distribution, and 
the follow up of autoimmune patients in which an established lung involvement is known. However, patients can remain asymptomatic for lung time despite evidence of lung involvement already being present ("Velcro" crackles in auscultation, impaired PFTs or evidence of lung involvement in chest imaging) [2,3]. In view of this, PFTs can also represent a useful, inexpensive and safe tool for the diagnosis of lung disease in CTDs and its management in the early stages, in which the disease could be more responsive to treatment.

The aim of this paper is to review lung involvement in CTD and highlight the role of PFTs in its diagnosis and follow up.

\section{Rheumatoid arthritis}

Rheumatoid Arthritis (RA) is an autoimmune, potentially systemic disease characterized by an inflammatory, symmetric, additive and erosive arthritis affecting about $1 \%$ of the population of developed countries [4]. The pathogenesis of the disease is currently not fully understood, but the lung seems to be a possible source of autoimmunity. Exposure to dust and smoke can lead to the citrullination of peptides, provoking an autoimmune response, with the production of Anti Cyclic Citrullinated Antibodies (ACPA) which represent one of the most specific items for the diagnosis [5, 6]. Probably due to autoimmune mechanisms, RA can be directly associated with respiratory system damage not only with ILD, but also with bronchiectasis, pleural effusion, rheumatoid parenchymal nodules and, rarely, vascular disease. Indirectly RA-associated respiratory damage (generally with ILD or respiratory tract infections) can be caused by the drugs used for treatment [7].

RA-ILD occurs in $4-68 \%$ of patients depending on the criteria used for identification, while $10 \%$ of RA patients showed clinically relevant ILD $[8,9]$. The most common pattern in High-Resolution Chest Tomography (HRCT) or Surgical Lung Biopsy (SLB) is Usual Interstitial Pneumonia (UIP), followed by Nonspecific Interstitial Pneumonia (NSIP) and rarely other patterns [7]. Risk factors linked to RA-ILD are age, male sex, smoking history, positivity for ACPA, longstanding and/or persistently active disease, presence of rheumatoid nodules and articular erosions, and genetic predisposition with several Human Leukocytes Antigens (HLAs) [10, 11]. A worse prognosis is reported in UIP pattern rather than NSIP or Organized Pneumonia (OP), but currently there is no consensus in the literature on whether a specific HRCT pattern in RA-ILD has a similar or better prognosis compared to the same pattern in Idiopathic Interstitial Pneumonia (IIP) or Idiopathic Pulmonary Fibrosis (IPF) [10]. Female sex and higher levels of Carbon Monoxide Diffusing Capacity $\left(\mathrm{DL}_{\mathrm{CO}}\right)$ were associated with a better prognosis [12].
RA patients can also develop OLD, mainly Chronic Obstructive Pulmonary Disease (COPD), Bronchiectasis (BR) and bronchiolitis associated with ILD. COPD is obviously the most frequent OLD in RA [13]. A history of smoking plays a crucial role, but regardless of this, RA showed a pooled risk ratio of OLD of 1.99 even in non-smoker patients [14], with a mortality comparable to RA-ILD [15].

Finally, RA was also associated with Combined Pulmonary Fibrosis and Emphysema (CPFE), a syndrome often characterized by severe dyspnoea, preserved lung volumes and severe reduction of $\mathrm{DL}_{\mathrm{CO}}$, with emphysema localized in the upper lobes and ILD in the lower ones and possible development of PAH [16]. Initially described in patients with a history of smoking, it was described in $27 \%$ of RA-ILD patients who had never smoked and it was independently associated with higher mortality [17]. PFTs appear to be able to predict the evolution of RA-ILD. Lower Forced Vital Capacity (FVC) and $\mathrm{DL}_{\mathrm{CO}}$ and their decline over 6 months are associated with a severe disease [18], while $\mathrm{DL}_{\mathrm{CO}} \leq 54 \%$ was identified as a cut-off for RA-ILD progression with sensitivity of $80 \%$ and specificity of $93 \%$ [19]. Another interesting study correlated mortality with a FVC lower than $61.8 \%$ of that predicted at the baseline or a decline of $10 \%$ from the baseline in any time [20]. In the same study, adjusting data for age, sex and smoking, a specific HRCT pattern was not associated with survival. Instead, the six-minute walk test (6MWT) during RA-ILD was not studied in depth, probably due to possible impairment caused by articular disease.

Despite the fact that pulmonary involvement is the most common extra-articular manifestation of RA with an impact on prognosis, guidelines for the management of lung involvement during RA are not currently available. Generally, RA patients were studied for lung involvement at the onset of suggestive symptoms. However, as already mentioned, several ILDs are able to produce a decline in PFTs in patients who were initially asymptomatic [2, 3]. Moreover, a UIP pattern in RA-ILD is associated with a longer disease duration, leading some authors to theorise a progression from a NSIP pattern [12]. In view of this concept, it could be useful to determine ILD before structural damage, in order to tailor appropriate treatment. Indeed, increasing evidence suggests the use of anti-fibrotic drugs for the treatment of RA-ILD [21] and it appears reasonable to suppose that this could be a new indication for these drugs in the future.

The recognition of lung involvement in RA can also be useful in the management of the disease. In fact, several treatments for RA were associated with the development or the exacerbation of a pre-existing ILD, mainly Methotrexate and TNF $\alpha$ blockers [22, 23]. 
Patients with RA-ILD may benefit from the use of Tocilizumab and Abatacept, two biologic drugs to date not associated with fibrotic lung involvement [24]. Moreover, the early recognition of OLD could allow the elimination of modifiable risk factors, and drive the treatment towards the use of drugs with a lower risk of pulmonary infections [25].

In our opinion, a physical examination looking for "Velcro" crackles and PFTs should be performed in all new diagnoses of RA, and repeated at least every 12 months. HRCT should be reserved for RA patients with a positive physical examination, impaired PFTs at baseline or reduction of 10 and $15 \%$ respectively for $\mathrm{FVC}$ and $\mathrm{DL}_{\mathrm{CO}}$ at $6-12$ months, according to international guidelines for IIPs [26].

In the event that the clinical picture suggests CPFE, the issue of preserved lung volumes would mean that the only screening possible for these patients would be based on a clinical examination of their reduced $\mathrm{DL}_{\mathrm{CO}}$, which could then be studied in depth by HRCT and echocardiogram.

\section{Scleroderma spectrum disorders}

The most important disease considered in Scleroderma Spectrum Disorders (SSDs) is Systemic Sclerosis (SSc). The disease affects about 1 out of 10,000 persons [27] and is characterized by fibrosis of the skin and internal organs, Raynaud Phenomenon (RP) and vasculopathy. SSc is classically subdivided into 4 expressions according to skin involvement: Diffuse SSc (dSSc), Limited SSc (ISSc), SSc sine scleroderma (ssSSc) and Overlap Syndromes (OS), in which classic sclerodermic signs are associated with features typical of other CTDs [28]. SSc is the most severe CTD and lung involvement is the major cause of death both for ILD and PAH [29]. Serological positivity can serve as a marker of lung involvement: Scl70 positivity is associated with ILD, while Anticentromeric antibodies (ACA), anti RNA polymerase I, II and III (above all when associated with U1RNP positivity) are associated with PAH and a worse prognosis. Moreover, Th/To antibodies are associated with ILD preceding $\mathrm{PAH}$, mainly in patients with ssSSc [30].

Scleroderma-related ILD is mainly characterized by an NSIP pattern on HRCT, followed by UIP. ILD affects about $80 \%$ of SSc patients, but only $25-30 \%$ will develop progressive disease within 5 years of the disease onset (counted from the first non-RP scleroderma sign) that will stabilise into structural damage in 4-6 years [28]. It can be classified into limited and diffuse ILD according to Goh's staging system, correlating with a worse prognosis for a disease extent threshold $\geq 20 \%$ [31].

On the other hand, PAH affects about $15 \%$ of SSc patients, with a worse prognosis than the idiopathic form [29]. SSc-PAH can arise from different pathogenic mechanisms: caused by disease of the small pulmonary arteries (group $1 \mathrm{PAH}$, mainly in $\mathrm{ISSc}$ patients), due to myocardial fibrosis (rarely, group $2 \mathrm{PAH}$ ), or secondary to ILD (group $3 \mathrm{PAH}$, mainly in dSSc patients) [32].

Finally, OLD can also be found in in SSc patients. CPFE was described in $12.3 \%$ of patients, a few of whom were non-smokers [33].

Unfortunately, the use of PFTs in SSc appears to be less useful than in RA-ILD or IPF. This is understandable, taking into account that SSc has different pathogenic mechanisms and generally a different HRCT pattern than RA and IPF. In fact, unlike IPF, the use of FVC as a good predictor of lung ILD severity is not sufficiently supported, despite its wide use as a primary outcome in clinical trials. Five validation studies were undertaken to study the best PFT items, but in a recent meta-analysis no items from PFTs showed good sensitivity or specificity for the early diagnosis of ILD [34]. Therefore, an HRCT should be performed in all new diagnoses of SSc, especially for dSSc.

Also in follow up, ILD extension was associated with FVC and $\mathrm{DL}_{\mathrm{CO}}$ only at the baseline, but not with their decline [35]. FVC showed high variability among SSc patients, with even amelioration from low baseline levels: a fast decline was experienced mainly in patients with early disease [36]. In contrast, using baseline data from Scleroderma Lung Study I and II, $\mathrm{DL}_{\mathrm{CO}}$ provides the best estimate of ILD measured with HRCT quantification [37], at least in patients without $\mathrm{PAH}$ [38]. $\mathrm{DL}_{\mathrm{CO}}$ is useful not only in the prediction of disease severity, but also in the early forecast of organ damage, in the estimation of disease activity (DA) and correlates with DA index in Nailfold Videocapillaroscopy (NVC) [39-42]. Obviously, $\mathrm{DL}_{\mathrm{CO}}$ can be reduced by the presence of $\mathrm{PAH}$ [43]. This data reduces the specificity of $\mathrm{DL}_{\mathrm{CO}}$ in the description of SSc-ILD and should be taken into account in its interpretation. Finally, Total Lung Capacity (TLC) also showed good correlationas a measure of ILD severity, but needs to be studied more extensively [31]. It is likely that, as suggested by Caron et al. in their interesting meta-analysis [34], a composite index could better describe SSc-ILD extension and severity than the use of a single item alone. The Outcome Measures in Rheumatology (OMERACT) proposed a decline of FVC $\geq 10 \%$ or a reduction of $\geq 5$ to $<10 \%$ with a decline of $\mathrm{DL}_{\mathrm{CO}} \geq 15 \%$ to define ILD progression, but these measures need to be validated [44].

A similar point can be made for the detection of PAH. The diagnosis should be confirmed with Right Heart Catheterization (RHC), but several PFT items can be used for screening. An isolated reduction of $\mathrm{DL}_{\mathrm{CO}} \leq 55 \%$ without significant ILD and an FVC/DLCO ratio $>1.6$ were found to be useful in forecasting future $\mathrm{PAH}$ in patients with SSc [45]. Unfortunately, $\mathrm{DL}_{\mathrm{CO}}$ can be biased 
by frequently occurring concomitant ILD that can contribute to its reduction. A subdivision of $\mathrm{DL}_{\mathrm{CO}}$ into two transfer components (membrane conductance for $\mathrm{CO}$ and alveolar capillary blood volume) has been proposed as an ideal solution. This partition can be calculated combining $\mathrm{DL}_{\mathrm{CO}}$ with the transfer factor of the lung for nitric oxide (TLNO) [46]. However, a large study reported that the combined measurement of $\mathrm{DL}_{\mathrm{CO}}$ and TLNO does not improve the recognition of SSc-PAH [47]. Therefore, currently the most sensitive method to screen SSc patients for PAH is a composite, two-step, algorithm named DETECT. Items considered in this algorithm are: $\mathrm{FVC} / \mathrm{DL}_{\mathrm{CO}}$ ratio, presence of $\mathrm{ACA}$ and telangiectasias, serum level of NT-proBNP and urate, presence of right axis deviation on Electrocardiogram, right atrium area and tricuspid velocity in echocardiography. DETECT showed better performance than the International European Society of Cardiology/European Respiratory Society guidelines in the diagnosis of SSc-PAH [48].

Mixed Connective Tissue Disease (MCTD) could be considered in SSDs. This autoimmune disease is characterized by the presence of the U1-RNP antibody and clinical features of SSc, Systemic Lupus Erythematosus (SLE) and Polymyositis/Dermatomyositis (PM/DM) [49]. The annual incidence of MCTD is about 1.9 per 100,000 population, with a mortality similar to general population [49]. It is still a matter of debate whether MCTD should be considered a separate entity or a form of Undifferentiated Connective Tissue Disease (UCTD)/OS, considering that the clinical picture for MCTD usually becomes clear within 3.6 years, but the rate of differentiation in other CTDs in 10 years of follow up is low $(8.5 \%$ for SLE and 6.3\% for SSc) [49].

Pulmonary involvement, particularly $\mathrm{PAH}$, is the major cause of death in MCTD patients [50]. ILD in MCTD usually shows an NSIP pattern, followed by UIP and it occurs in about $50 \%$ of patients [51]. Out of these, 19\% show a severe, rapidly progressive ILD, with a mortality of $20 \%$ in a follow up of 4.2 years [52]. On the other hand, PAH occurs in about $10 \%$ of patients, associated with antiphospholipid (APLA) and anti-endothelial cell antibody positivity, presence of NVC alterations and RP, but generally without significant ILD [53]. Compared to SSc, MCTD-PAH seems to debut at a younger age and have a comparable 1-year survival [54].

A division into three subsets of MCTD patients was proposed: subgroup 1 with vascular damage, mainly characterized by PAH, RP and NVC positivity, subgroup 2 with ILD and myositis and subgroup 3 (with a better prognosis) featuring arthritis, articular erosions and ACPA positivity similar to RA [55].

Unfortunately, evidence regarding the role of PFTs in literature is limited. FVC and TLC proved to be stable in
MCTD over ten years, while $\mathrm{DL}_{\mathrm{CO}}$ showed a reduction [56]. $\mathrm{DL}_{\mathrm{CO}}$ also correlated with active ILD [57], confirming its superior sensitivity in detecting ILD. Considering that PAH and ILD in MCTD and SSC are likely to have a similar pathogenic mechanism, a reasonable guide for the follow up of these patients could be derived from what is suggested for SSc.

\section{Idiopathic inflammatory myositis}

The family of Idiopathic Inflammatory Myositis (IIMs) was traditionally used to categorize a group of autoimmune diseases characterized by muscle weakness caused by damage to skeletal muscle. The family are considered PM, DM, Necrotizing Autoimmune Myositis and Inclusion Body Myositis [58]. Except for the latter two diseases, these conditions are widely associated with visceral involvement, mainly of the skin and lung which may influence the prognosis. This classification is still under debate, with the aim of considering antibodies positivity and including other conditions such as Antisynthetase Syndrome (AS) [59]. This syndrome is characterized by the presence of the classic triad of myositis, ILD and inflammatory arthritis, in which RP, mechanic hands and unexplained fever may occur [60]. The incidence of PM and DM is calculated at about 6-7 per million [61] but is probably significantly underestimated based on the clinical presentation of these patients. Frequently, lung involvement is the unique clinical manifestation at disease onset, but during follow up the majority of these patients will develop the other clinical manifestations of the disease [62, 63]. Moreover, Sontheimer identified clinical subsets of patients without significant muscle involvement but the presence of typical skin involvement (Gottron's papules and sign, mechanic hands, heliotrope rash) and the possibility of developing an ILD with a worse prognosis than DM $[64,65]$. This condition is named Clinically Amyopathic Dermatomyositis (CADM). At present, validated criteria for AS are not available. However, several patients classified as Interstitial Pneumonia with Autoimmune Features (IPAF) for an ILD associated with Anti tRNA Synthetase Antibodies (ATSA), should be classified for both IPAF or AS depending on the referral centre [66, 67].

ILD affects about $65 \%$ of PM/DM patients, in a clinically relevant subset in $17-36 \%$ of patients, and proved to be a cause of death in about $50 \%$ of patients, especially in a subset of rapidly progressive ILD with positivity for MDA5 antibodies $[67,68]$. The most common HRCT pattern is NSIP, but often an Organising Pneumonia (OP), alone or an overlap NSIP-OP, can be found [69]. AS showed similar HRCT patterns, but at higher prevalence, with up to $90 \%$ of patients with ILD [70, 71]. AS-ILD prognosis is related to specific ATSA positivity: anti Jo1 positive patients generally have myositis and 
arthritis with better outcome in ILD, while PL7 and PL12 positive patients showed a worse prognosis due to rapidly progressive ILD [72].

Few studies in the literature have investigated the role of PAH in IIMs. It was found in 16\% of PM patients, mainly associated with Pericardial Effusion (PE) and diffuse ILD [73]. However, a large cohort of PAH patients showed IIMs in only 34 out of 5,223 patients, of which there were only 3 without significant ILD [74]. These patients had DM, and PAH was associated with SSA/Ro antibody positivity and, similar to SSc and MCTD, with skin involvement and peripheral microangiopathy. Finally, in AS a PAH was demonstrated in 16 out of 201 patients, generally associated with severe ILD. AS-PAH patients are more likely to have polyarthralgia and longstanding disease. The authors reported a 3-year survival rate of $58 \%$ but they did not find any correlation with ATSA positivity [75].

Sporadically both a restrictive disease and PAH in IIMs could be found, mainly due to muscle weakness, secondary to respiratory or cardiac muscle involvement. Several case reports are reported in literature.

Regarding PFTs, an FVC\% $<60$ in IIMs was correlated with a worse prognosis [76], together with Hamann Rich presentation, CADM, older age and acute/subacute onset of ILD [77]. FVC seems to be able to predict the response to therapy: in one small-scale study the decrease in the extent of ground glass opacities correlated inversely with changes in FVC [78]. FVC and $\mathrm{DL}_{\mathrm{CO}}$ showed also correlation at baseline with disease extent on HRCT (with major sensitivity for $\mathrm{DL}_{\mathrm{CO}}$ ) [79]. This data was confirmed with the CALIPER software, but after a 1-year follow up, a significant correlation was found only for TLC [80].

\section{SJÖGREN'S}

$\mathrm{Sj}$ gren's Syndrome $(\mathrm{SjS})$ is a chronic autoimmune disease involving about $0.06 \%$ of the population characterized mainly by Sicca syndrome, due to damage to the lacrimal and salivary glands [81]. SjS pathogenesis is not completely understood yet, but B cells and a $\mathrm{T}$ helper type 1 and 17 responses play a key role, explaining the potential systemic involvement (lung involvement, vasculitis and lymphomagenesis) [82].

The most common SjS lung involvement is an obstructive disease with bronchial hyperresponsiveness (42-60\% of patients) often insensitive to inhaled corticosteroids, bronchiolitis (12-24\% of patients) and BR (7$54 \%$ of patients) [83]. The mechanism underlying these conditions seems to be local dryness in the upper respiratory tract, alteration in mucociliary clearance and the presence of hyperplastic lymphoid follicles with reactive germinal centres similar to those present in salivary glands. This impaired muco-ciliary clearance can expose patients to infective pneumonia, reported in $10-35 \%$ of patients [83].

ILD is present in $9-20 \%$ of patients. The most common HRCT pattern is NSIP (45\%) followed by UIP, Lymphocitic Interstitial Pneumonia and OP $(16,15,7 \%$ respectively, other conditions in 17\%) [84].

ILD in SjS is generally stable [85], while it can be accelerated when associated with hypergammaglobulinemia, lymphopenia, reduction of FVC and positivity for Rheumatoid Factor (RF), SSa/Ro and SSb/La with low sensitivity but high specificity [86].

$\mathrm{PAH}$ is rarely reported in literature for $\mathrm{SjS}$ with some case reports. Despite these, echocardiographic elements suggestive of $\mathrm{PAH}$ are reported in about $25 \%$ of patients [87]. PAH is a severe condition, but, unlike other conditions, can benefit from immunosuppressant therapy [88]. $\mathrm{PAH}$ was also associated in $\mathrm{SjS}$ patients with the presence of RP, PE, hepatic injury and high titre of RF [89].

In summary, both PAH and ILD showed contradictory data. A possible explanation could be the evidence that both these conditions can have their onset years before the complete manifestation of $\mathrm{SjS}$ [83, 89]. Moreover, it is possible that patients with severe lung involvement that could have an impact on their prognosis, tend to be referred to a specialist perceived to be more relevant to their condition, bypassing the rheumatologist.

Regarding PFTs, few data are reported in the literature. A common finding is the reduction of Vital Capacity $(\mathrm{VC})$, Forced Expiratory Volume at $1 \mathrm{~s}\left(\mathrm{FEV}_{1}\right), \mathrm{FEV}_{1} / \mathrm{VC}$ ratio and $\mathrm{DL}_{\mathrm{CO}}$, signalling an obstructive disease, even in non-smoking patients [90]. Obviously, an overlapping restrictive disease should be taken into account. During ILD, good correlation was found at baseline between $\mathrm{DL}_{\mathrm{CO}}$ and TLC and the scores of ground-glass attenuations [91].

\section{Systemic lupus erythematosus}

SLE is a chronic autoimmune disease potentially able to cause a systemic involvement (skin, kidney, blood, central and peripheral nervous system, etc) characterized by a deposition of immune complexes leading to organ damage [92]. Although lung involvement is not considered separately in SLE classification criteria [93], the disease is able to damage the whole respiratory tract at each level [94]. Upper airway involvement includes nasal ulcers (considered in SLE classification criteria), mucosal inflammation and sporadically severe airway obstruction with respiratory failure [94]. The most common involvement is pleurisy (also considered in SLE criteria), that can involve up to $60 \%$ of patients [95]. Another extra-parenchymal manifestation of SLE is Shrinking Lung Syndrome (SLS), a rare complication characterized by a restrictive disease without parenchymal involvement due to diaphragmatic dysfunction. This condition 
could affect up to $10 \%$ of patients [96]. ILD affects about $15 \%$ of SLE patients, generally with NSIP pattern [97]. SLE-ILD patients often showed a better prognosis than that seen in idiopathic forms or other CTDs. Severe parenchymal manifestations are Acute Lupus Pneumonitis (ALP) and Diffuse Alveolar Damage (DAD). The first is an acute form that involves about $1-4 \%$ of patients with an active flare of the disease and SSa/Ro positivity [98] that is hard to distinguish from infective pneumonia. DAD is a life-threatening complication that affects about $2 \%$ of patients and is characterized by damage to the alveolar-capillary membrane, generally associated with positivity for antiphospholipid antibodies (APLA) [99].

SLE is also the second autoimmune cause of PAH, with a prevalence of $0.6-17 \%$ of patients [100]. Multiple pathogenic pathways can be implicated in pathogenesis (vasculitis, pro-thrombotic state secondary to the presence of APLA, cardiac and valvular dysfunction, ILD and SLS). Therefore, SLE-PAH can be potentially classified in each PAH group, but increasing evidence suggests the utility of immunosuppressive therapy (jointly with vasodilators) for its management [94, 100].

Regarding PFTs, little evidence is available, probably due to the fact that severe lung involvement is rare and usually acute, while a chronic disease generally shows a slow decline and a good prognosis.

A reduction in $\mathrm{DL}_{\mathrm{CO}}$ is reported in about $38 \%$ of asymptomatic SLE patients, but after a follow up period of 9 years none of these patients developed a lung disease [101], therefore this reduction seems not to be useful in predicting future lung involvement in SLE patients. A reduction in Maximum Voluntary Ventilation without a significant impairment in $\mathrm{FEV}_{1}$ and $\mathrm{FVC}$ was also noted in SLE patients, leading to the conclusion that fatigue, a common symptom in the disease, could also involve the respiratory muscles [102]. Regarding 6MWT, a Heart Rate Recovery (difference between Heart rate at the end of 6MWT and after 1,2 and $3 \mathrm{~min}$ of rest) $<16$ was associated with a worse prognosis in patients with CTD-PAH (group composed of patients with ISSc, dSSc, MCTD, SLE) [103].

\section{Other conditions}

The prevalence of lung involvement in UCTD has not been adequately studied. The major problem is a lack of consensus on classification criteria for UCTD and possible selection bias. Indeed, UCTD can represent an incomplete form or an early onset of CTD and it is reasonable to suppose that individual patients are usually referred to a specialist in the specific organs involved. In 2015, classification criteria for Interstitial Pneumonia with Autoimmune Features (IPAF) were proposed, in order to recruit these forms with ILD involvement [104]. Currently no prospective data are available in literature, but several retrospective studies report a heterogeneous population [66]. An improvement of these criteria could be useful for the earlier recruitment of CTD-ILD, in order to exploit a window of opportunity before the development of a structural damage.

An interesting speculation can also be made regarding Antiphospholipid Syndrome (APS). This is an autoimmune disease characterized by the presence of venous/ arterial thrombosis or obstetrical morbidity associated to the positivity for APLA and Lupus Anticoagulant (LAC). APS often overlaps with CTDs (mainly SLE) and is associated with PAH and pulmonary embolism [105]. As already mentioned, the presence of APL can predict PAH in SLE [99]. Sporadically, ILD in APS was reported. Conversely, it

Table 1 Risk factors for Chronic Pulmonary Disease in CTDs

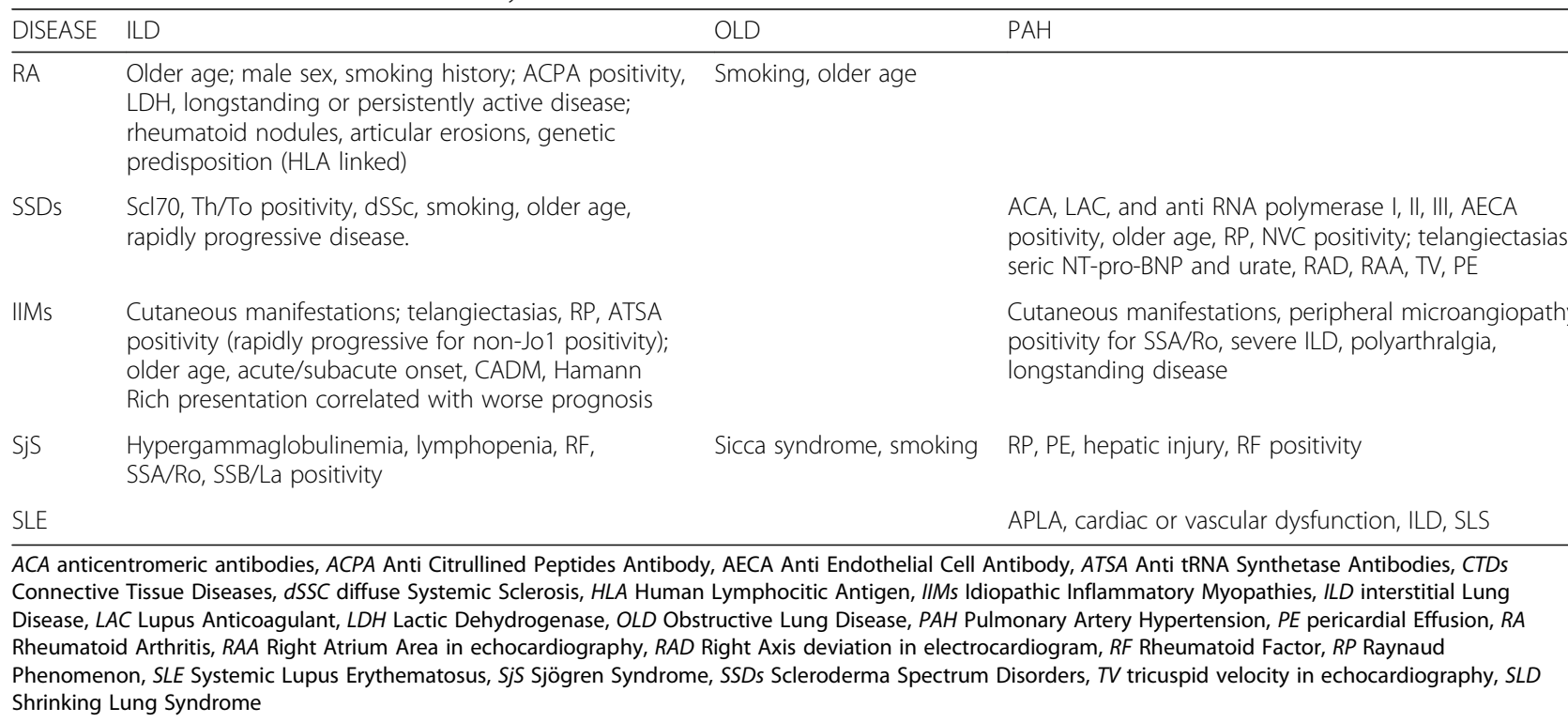


should be noted that APLA are frequently discovered in IPF patients, and a LAC positivity was found in about $20 \%$ of patients [106]. Moreover, these patients frequently had vascular thrombosis, therefore satisfying classification criteria for APS [107]. The percentage of LAC positivity in IPF patients appears to be very high, considering the incidence of LAC positivity in the general population (1-5\%, [108]) and in SLE (34.1\%, [109]), potentially explaining the pro-thrombotic state evidenced in the disease [110].

\section{Conclusions}

The evolution of CTD-ILD varies significantly in each patient: some identified risk factors for diagnosis and prognosis are reported in Table 1. Considering the different pathogenic pathways and manifestations of lung involvement in CTDs, a translation of the PFTs indications and their significance from IPF to CTDs

Table 2 Significance of PFTs in Chronic Lung involvement due to CTDs

\begin{tabular}{|c|c|c|}
\hline Disease & Items & Correlation \\
\hline \multicolumn{3}{|l|}{ RA } \\
\hline \multirow[t]{2}{*}{ ILD } & $\begin{array}{l}\text { Decline of } \mathrm{FVC} \geq 10 \% \\
\text { from } 68.7 \text { or any time } \\
\text { from baseline } \\
\text { Decline of } \mathrm{DL} \text { co } \% \geq 10 \% \\
\text { from } 48.1 \text { or any time } \\
\text { from baseline }\end{array}$ & Mortality \\
\hline & $\begin{array}{l}\mathrm{DL} \text { CO } \leq 54 \\
\text { FVC decline } \geq 10 \% \\
\text { DL } 2 \text { decline } \geq 15 \%\end{array}$ & Progression \\
\hline \multicolumn{3}{|l|}{ SSDs } \\
\hline \multirow[t]{2}{*}{ ILD } & $\begin{array}{l}\text { Decline of FVC } \geq 10 \% \\
\text { or comprised between } \\
5 \text { and } 10 \% \text { with a } \\
\text { decline of } D L_{C O} \geq 15 \%\end{array}$ & Progression \\
\hline & $\mathrm{DL}_{\mathrm{CO}}<80$ & Clinical and NVC DA \\
\hline \multirow[t]{2}{*}{$\mathrm{PAH}$} & $\mathrm{DL}_{\mathrm{CO}} \leq 55$ & diagnosis \\
\hline & $\mathrm{FVC/DL}$ CO $>1.6$ & diagnosis \\
\hline \multicolumn{3}{|l|}{ IIMs } \\
\hline \multirow[t]{2}{*}{ ILD } & $\mathrm{FVC} \leq 60$ & prognosis \\
\hline & TLC & Disease extent in FU \\
\hline \multicolumn{3}{|l|}{ SjS } \\
\hline OLD & $\begin{array}{l}\text { Reduction of } \mathrm{VC}, \mathrm{FEV}_{1}, \\
\mathrm{FEV}_{1} / \mathrm{NC}, \mathrm{DL}_{\mathrm{CO}}\end{array}$ & Diagnosis and prognosis \\
\hline ILD & $\mathrm{DL}_{\mathrm{CO}}, \mathrm{TLC}$ & $\begin{array}{l}\text { Correlation with disease } \\
\text { extent }\end{array}$ \\
\hline \multicolumn{3}{|l|}{ SLE } \\
\hline $\mathrm{PAH}$ & $\mathrm{HRR}<16$ & prognosis \\
\hline \multicolumn{3}{|c|}{$\begin{array}{l}\text { DA Disease Activity, DLCO diffusing capacity for carbon monoxide, FEV1 Forced } \\
\text { Expiratory Volume in } 1 \mathrm{~s} \text {, FVC forced vital Capacity, HRR heart Rate Recovery, } \\
\text { IIMs Idiopathic Inflammatory Myopathies, ILD Interstitial Lung Disease, NVC } \\
\text { Nailfold Videocapillaroscopy, PAH Pulmonary Artery Hypertension, PFT } \\
\text { Pulmonary Function Test, RA Rheumatoid Arthritis, SjS Sjögren Syndrome, SLE } \\
\text { Systemic Lupus Erythematosus, SSDs Scleroderma Spectrum Disorders, TLC } \\
\text { Total Lung Capacity, VC Vital Capacity }\end{array}$} \\
\hline
\end{tabular}

should be made with caution. Table 2 summarizes the PTFs' significance in CTDs.

The high incidence of ILD in CTD suggest that PFTs, jointly with physical examinations, should be performed in all new diagnoses and repeated periodically regardless of referred symptoms. In RA, PFTs can be useful for highlighting an asymptomatic ILD before its clinical onset [3], and it could be useful to tailor appropriate immunosuppressive drugs. Similar data were reported for SSc [2], but not for SLE [101]. In patients with SSDs and IIMs, the frequency and the severity of chronic lung involvement suggest that it would be wise to perform an HRCT jointly with PFTs in all new patients, but PFT items appear to be less accurate than in IPF in the description of lung function during the course of the disease or in response to treatment. Considering this, a composite index could be more useful than the evaluation of a single item.

In view of this, more exhaustive studies regarding risk factors together with PTFs could be useful for early diagnosis and treatment before the stabilization of a structural damage, improving both patient survival and quality of life.

Acknowledgements

None.

Availability of data and material

Not applicable.

\section{Funding}

This work was supported by the Departmental Project \#A Objective 2 Group of Analysis 2, "molecular, clinical and instrumental early markers in metabolic and chronic-degenerative diseases" of the Clinical Medicine Dept, University of Catania.

\section{Authors' contributions}

Study conception and design: NC, GS. Acquisition of data: NC, GS, MP, AV, SET, DS. All authors were involved in the analysis and interpretation of data, in drafting the article and/or revising it critically for importan intellectual content. All authors approved the final version. NC take responsibility for the integrity of the data and the accuracy of the data analysis.

Ethics approval and consent to participate

Not applicable.

\section{Consent for publication}

Not applicable.

\section{Competing interests}

CV is part of the F. Hoffmann-La Roche Ltd. Scientific board. He has received consulting fees and/or speaker fees from AstraZeneca, Boehringerlngelheim, Chiesi, F. Hoffmann-La Roche Ltd. and Menarini. FDM has participated as a lectures, speaker, and/or advisor in scientific meetings and courses under the sponsorhip of Almirall, AstraZeneca, Boehringer Ingelheim, Chiesi Farmaceutici, Dompè, Guidotti/Malesci, GlaxoSmithKline, Menarini Group, Novartis, and Zambon, and has received financial suppor for research from Novartis. The authors NC, GS, DS, MP, AV, SET declare that they have no conflict of interest.

\section{Publisher's Note}

Springer Nature remains neutral with regard to jurisdictional claims in published maps and institutional affiliations. 


\section{Author details}

'Regional Referral Center for Rare Lung Diseases, A. O. U. "Policlinico-Vittorio Emanuele" Department of Clinical and Experimental Medicine, University of Catania, Catania, Italy. ${ }^{2}$ Respiratory Physiopathology Group. Società Italiana di Pneumologia. Italian Respiratory Society (SIP/IRS), Milan, Italy. ${ }^{3}$ Artroreuma S.R.L. Outpatient Clinic accredited with the Italian National Health System, Corso S. Vito 53, 95030 Mascalucia (CT), Italy. ${ }^{4}$ Department of Medical Surgical Sciences and Advanced Technologies- Radiology I Unit, University Hospital "Policlinico-Vittorio Emanuele", Catania, Italy. ${ }^{5}$ Department of Health Sciences, Università degli studi di Milano, Head Respiratory Unit, Papa Giovanni XXIII Hospital, Bergamo, Italy.

Received: 20 November 2018 Accepted: 15 March 2019 Published online: 15 May 2019

\section{References}

1. Atzeni F, Gerardi MC, Barilaro G, Masala IF, Benucci M, Sarzi-Puttini P. Interstitial lung disease in systemic autoimmune rheumatic disease: a comprehensive review. Expert Rev Clin Immunol. 2018;14(1):69-82. https:// doi.org/10.1080/1744666X.2018.1411190.

2. Hassoun PM. Lung involvement in systemic sclerosis. Presse Med. 2011;40(1 Pt 2):e3-e17. https://doi.org/10.1016/j.lpm.2010.08.006.

3. Chen J, Shi $Y$, Wang $X$, Huang $H$, Ascherman D. Asympyomatic preclinical rheumatoid-arthritis-associated interstitial lung disease. Clin Dev Immunol. 2013;2013:406927. https://doi.org/10.1155/2013/406927.

4. Myasoedova E, Crowson CS, Kremers HM, Therneau TM, Gabriel SE. Is the incidence of rheumatoid arthritis rising?: results from Olmsted County, Minnesota, 1995-2007. Arthr Rheum. 2010;62(6):1576-82. https://doi.org/10. 1002/art.27425.

5. Cafaro G, Alunno A, Valentini V, Leone MC, Marcucci E, Bartoloni E, Gerli R. The onset site of rheumatoid arthritis: the joints or the lung? Reumatismo. 2016;68(4):167-75. https://doi.org/10.4081/reumatismo.2016.892.

6. Hensvold AH, Frisell T, Magnusson PK, Holmdahl R, Askling J, Catrina Al. How well do ACPA discriminate and predict RA in the general population: a study based on 12590 population-representative Swedish twins. Ann Rheum Dis. 2017;76(1):119-25. https://doi.org/10.1136/annrheumdis-2015-208980.

7. Shaw M, Collins BF, Ho LA, Raghu G. Rheumatoid arthritis-associated lung disease. Eur Respir Rev. 2015;24:1-16. https://doi.org/10.1183/09059180. 00008014.

8. Kim EJ, Collard HR, King TE Jr. Rheumatoid-arthritis-associated interstitial lung disease. Chest. 2009;136(5):1397-405. https://doi.org/10.1378/chest.09-0444.

9. Doyle TJ, Lee JS, Dellaripa PF, Lederer JA, Matteson EL, Fischer A, et al. A roadmap to promote clinical and translational research in rheumatoid arthritis-associated interstitial lung disease. Chest. 2014;145(3):454-63. https://doi.org/10.1378/chest.13-2408.

10. Igbal K, Kelly C. Treatment of rheumatoid arthritis-associated interstitial lung disease: a perspective review. Ther Adv Musculoskelet Dis. 2015;7(6):247-67. https://doi.org/10.1177/1759720X15612250.

11. Zhang Y, Li H, Wu N, Dong X, Zheng Y. Retrospective study of the clinical characteristics and risk factors of rheumatoid-arthritis associated interstitial lung disease. Clin Rheumatol. 2017;36(4):817-23. https://doi.org/10.1007/ s10067-017-3561-5.

12. Kim EJ, Elicker BM, Maldonado F, Webb WR, Ryu JH, Van Uden JH, et al. Usual interstitial pneumonia in rheumatoid arthritis-associated interstitial lung disease. Eur Respir J. 2010;35:1322-8. https://doi.org/10.1183/09031936. 00092309.

13. Nannini C, Medina-Velazquez YF, Achenbach SJ, Crowson CS, Ryu JH, Vassallo R, et al. Incidence and mortality of obstructive lung disease in rheumatoid arthritis: a population-based study. Arthr Care Res (Hoboken). 2013;65(8):1243-50. https://doi.org/10.1002/acr21986.

14. Ungprasert P, Srivali N, Cheungpasitportn W, Davis lii JM. Risk of incident chronic obstructive pulmonary disease in patients with rheumatoid arthritis: a systematic review and meta-analysis. Joint Bone Spine. 2016;83(3):290-4. https://doi.org/10.1016/j.jbspin.2015.05.016.

15. Hyldgaard C, Ellingsen T, Bendstrup E. COPD an overlooked cause of excess mortality in patients with rheumatoid arthrtitis. The Lancet Resp Med. 2018; 6(5):326-7. https://doi.org/10.1016/s2213-2600(18)30056-0.

16. Cottin V, Cordier JF. Combined pulmonary fibrosis and emphysema in connective tissue disease. Curr Opin Pulm Med. 2012;18(5):418-27. https:// doi.org/10.1097/MCP.0b013e328356803b.
17. Jacob J, Song JW, Yoon HY, Cross G, Barnett J, Woo WL, et al. Prevalence and effects of emphysema in never-smokers with rheumatoid arthritis interstitial lung disease. Ebiomedicine. 2018;28:303-10. https://doi.org/10. 1016/j.ebiom.2018.01.038.

18. Zamora-Legoff JA, Krause ML, Crowson CS, Ryu JH, Mateson EL. Progressive decline of lung function in rheumatoid arthritis associated interstitial lung disease. Arthr Rheumatol. 2017;69(3):542-9. https://doi.org/10.1002/art.39971.

19. Dawson J, Fewins H, Desmon J, Lynch M, Graham D. Predictors of progression of HRCT diagnosed fibrosin alveolitis in patients with rheumatoid arthritis. Ann Rheum Dis. 2002;61(6):517-21. https://doi.org/10. 1136/ard.61.6.517.

20. Solomon JJ, Chung JH, Cosgrove GP, Demourelle MK, Fernandez-Perez ER Fischer A, et al. Predictors of mortality in rheumatoid arthritis-associated interstitial lung disease. Eur Respir J. 47(2):588-96. https://doi.org/10.1183/ 13993003.00357-2015.

21. Redente EF, Aguilar MA, Black BP, Edelman BL, Bahadur AN, Humphries SM, et al. Nintedanib reduces pulmonary fibrosis in a model of rheumatoid arthritis- associated interstitial lung disease. Am J Physiol Lung Cell Mol Physiol. 2018:314(6):L998-L1009. https://doi.org/10.1152/ajplung.00304.2017.

22. Hallowell $R$, Horton M. Interstitial lung disease in patients with rheumatoid arthritis: spontaneous and drug induced. Drugs. 2014;74:443-50. https://doi. org/10.1007/s40265-014-0190-z.

23. Nakashita T, Ando K, Kaneko N, Takahashi K, Motojima S. Potential risk of TNF inhibitors on the progression of interstitial lung disease in patients with rheumatoid arthritis. BMJ Open. 2014;4:e005615. https://doi.org/10.1136/ bmjopen-2014-005615.

24. Picchianti Diamanti A, Markovic M, Argento G, Glovagnoli S, Ricci A, Laganà $B$, et al. Therapeutic management of patients with rheumatoid arthritis and associated interstitial lung disease: case report and literature review. Ther Adv Respir Dis. 2017;11(1):64-72. https://doi.org/10.1177/1753465816668780.

25. Yun $H$, Xle F, Delzell E, Levitan EB, Chen L, Lewis JD, et al. Comparative risk of hospedalized infection associated with biologic agents in rheumatoid arthritis patients enrolled in medicare. Arthritis Rheumatol. 2016;68(1):56-66. https://doi.org/10.1002/art.39399.

26. Bluett J, Jani M, Symmons DPM. Practical management of respiratory comorbidities in patients with rheumatoid arthritis. Rheumatol Ther. 2017:4: 309-32. https://doi.org/10.1007/s40744-017-0071-5.

27. Jordan S, Maurer B, Toniolo M, Michel B, Distler O. Performance of the new ACR/EULAR classification criteria for systemic sclerosis in clinical practice. Rheumatology (Oxford). 2015;54(8):1454-8. https://doi.org/10.1093/ rheumatology/keu530.

28. Denton CP, Khanna D. Systemic sclerosis. Lancet. 2017;390(10103):1685-99. https://doi.org/10.1016/S0140-6736(17)30933-9.

29. Tyndall AJ, Bannert B, Vonk M, Airò P, Cozzi F, Carreira PE, et al. Causes and risk factors for death in systemic sclerosis: a study form the EULAR Scleroderma Trials and Research (EUSTAR) Database. Ann Rheum Dis. 2010; 69(10):1809-15. https://doi.org/10.1136/ard.2009.114264.

30. Mehra S, Walker J, Patterson K, Fritzler MJ. Autoantibodies in systemic sclerosis. Autoimmun Rev. 2013;12(3):340-54. https://doi.org/10.1016/j. autrev.2012.05.011

31. Goh NS, Desai SR, Veeraraghavan S, Hansell DM, Copley SJ, Maher TM, et al. Interstitial lung disease in systemic sclerosis: a simple stagin system. Am J Respir Crit Care Med. 2008;177(11):1248-54. https://doi.org/10.1164/rccm. 200706-8770C.

32. Launay D, Sobanski V, Hachulla E; Humbert M. Pulmonary hypertension in systemic sclerosis: different phenotypes. Eur Respir Rev 2017; 26 (145) pii 170056 doi: https://doi.org/10.1183/16000617.0056-2017

33. Antoniou KM, Margaritopoulos GA, Goh NS, Karagiannis K, Desai SR, Nicholson AG, et al. Combined pulmonary fibrosis and emphysema in scleroderma-related lung disease has a major confounding effect on lung physiology and screening for pulmonary hypertension. Arthr Rheumatol. 2016;68(4):1004-12. https://doi.org/10.1002/art.39528.

34. Caron M, Hoa S, Hudson M, Schwartzman K, Steele R. Pulmonary function tests as outcomes for systemic sclerosis interstitial lung disease. Eur Respir Rev. 2018; 27 pii 170102 doi: https://doi.org/10.1183/16000617.0102-2017

35. Le Gouellec N, Duhamel A, Perez T, Hachulla AL, Sobanski V, Faivre JB, et al. Predictors of lung function test severity and outcome in systemic sclerosisassociated interstitial lung disease. PLoS One. 2017;12(8):e0181692. https:// doi.org/10.1371/journal.pone.0181692.

36. Man A, Davidyock T, Ferguson LT, leong M, Zhang Y, Simms RW. Changes in forced vital capacity over time in systemic sclerosis: application of group 
based trajectory modelling. Rheumatology (Oxford). 2015;54(8):1464-71. https://doi.org/10.1093/rheumatology/kev016.

37. Tashkin DP, Volkmann ER, Tseng CH, Kim HJ, Goldin J, Clements P, et al. Relationship between quantitative assessments of interstitial lung disease and physiological and clinical features of systemic sclerosis. Ann Rheum Dis. 2016;75(2):374-81. https://doi.org/10.1136/annrheumdis-2014-206-076.

38. Valentini G, Della Rossa A, Bombardieri S, Bencivelli W, Silman AJ, D'Angelo $S$, et al. European multicentre study to define disease activity criteria for systemic sclerosis. II. Identification of disease activity variables and development of preliminart activity indexes. Ann Rhem Dis. 2001;60:592-8. https://doi.org/10.1136/ard.60.6.592

39. BellandoRandone S, Matucci-Cerinic M. Very early systemic sclerosis and pre-systemic sclerosis: definition, recognition, clinical relevance and future directions. Curr Rheumatol Rep. 2017;19(10):65. https://doi.org/10.1007/ s11926-017-0684-2.

40. Valentini G, ludici M, Walker AU, Jaeger VK, Baron M, Carreira P, et al. The European Scleroderma Trials and Research group (EUSTAR) task force for the development of revised activity criteria for systemic sclerosis: derivation and validation of a preliminary revised EUSTAR activity index. Ann Rheum Dis. 2017;76(1):270-6. https://doi.org/10.1136/annrheumdis-2016-209768.

41. Sambataro D, Sambataro G, Zaccara E, Maglione W, Polosa R, Afeltra AM, et al. Nailfold Videocapillaroscopy micro-haemorrhage and giant capillary counting asan accurate approach for a steady state definition of disease activity in systemic sclerosis. Arthritis Res Ther. 2014;16(5):462. https://doi. org/10.1186/s13075-014-0462-8

42. Andracco R, Irace R, Zaccara E, Vettori S, Maglione W, Riccardi A, et al. The cumulative number of micro-hemorrhages and micro-thromboses in nailfold videocapillaroscopy is a good indicator of disease activity in systemic sclerosis: a validation study of the NEMO score. Arthritis Res Ther. 2017:19(1):133. https://doi.org/10.1186/s13075-017-1354-5.

43. Hoeper MM, Bogaard HJ, Condliffe R, Frantz R, Khanna D, Kurzyna M, et al. Definitions and diagnosis of pulmonary hypertension. J Am Coll Cardiol. 2013;65(25 suppl):D42-50. https://doi.org/10.1016/j.acc.2013.10.032.

44. Khanna D, Mittoo S, Aggarwal R, Proudman SM, Dalbeth N, Matteson EL, et al. Connective tissue disease-associated interstitial lung disease (CTD-ILD)report from OMERACT CTD ILD working group. J Rheumatol. 2015;42(11): 2168-71. https://doi.org/10.3899/jrheum.141182.

45. Hsu VM, Chung L, Hummers LK, Wigley F, Simms R, Bolster M, et al. Development of pulmonary hypertension in a high-risk population with systemic sclerosis in the Pulmonary Hypertension Assessment and Recognition of Outcomes In Scleroderma (PHAROS) cohort study. Semin Arthritis Rheum. 2014;44(1):55-62. https://doi.org/10.1016/j.semarthrit.2014. 03.002 .

46. Martinot JB, Guénard H, AT DI-X, Gin H, Dromer C. Nitrogen monoxide and carbon monoxide transfer interpretation: state of the art. Clin Physiol Funct Imaging. 2017;37(4):357-65. https://doi.org/10.1111/cpf.12316

47. Degano B, Soumagne T, Delaye T, Berger P, Perez T, Guillien A, et al. Combined measurement of carbon monoxide and nitric oxide lung transfer does not improve the identification of pulmonary hypertension in systemic sclerosis. Eur Respir J. 2017;50(4): https://doi.org/10.1183/13993003.010082017.

48. Coghlan JG, Denton CP, Grunig E, Bonderman D, Distler O, Khanna D, et al. Evidence-based detection of pulmonary arterial hypertension in systemic sclerosis: the DETECT study. Ann Rheum Dis. 2014;73(7):1340-9. https://doi. org/10.1136/annrheumdis-2013-203301.

49. Ungprasert P, Crowson CS, Chowdhary VR, Ernste FC, Moder KG, Matteson EL. Epidemiology of mixed connective tissue disease, 1985-2014: a population-based study. Arthr Care Res (Hoboken). 2016;68(12):1843-8 https://doi.org/10.1002/acr.22872.

50. Vegh J, Szodoray P, Kappelmayer J, Csipo I, Udvardy M, Lakos G, et al. Clinical and immunoserological characteristics of mixed connective tissue disease associated with pulmonary arterial hypertension. Scand J Immunol. 2006;64(1):69-76. https://doi.org/10.1111/j.1365-3083.2006.01770.x.

51. Fagundes MN, Caleiro MT, Navarro-Rodriguez T, Baldi BG, Kavakama J, Salge $J M$, et al. Esophageal involvement and interstitial lung disease in mixed connective tissue disease. Respir Med. 2009;103(6):854-60. https://doi.org/ 10.1016/j.rmed.2008.12.018.

52. Gunnarsson R, Aalokken TM, Molberg O, Lund MB, Mynarek GK, Lexberg AS, et al. Prevalence and severity of interstitial lung disease in mixed connective tissue disease: a nationwide, cross-sectional study. Ann Rheum Dis. 2012; 71(12):1966-72. https://doi.org/10.1136/annrheumdis-2011-201253.
53. Ciang NC, Pereira N, Isenberg DA. Mixed connective tissue disease-enigma variations? Rheumatology (Oxford). 2017;56(3):326-33. https://doi.org/10. 1093/rheumatology/kew265.

54. Chung L, Liu J, Parsons L, Hassoun PM, McGoon M, Badesch DB, et al. Characterization of connective tissue disease-associated pulmonary arterial hypertension from REVEAL: identifying systemic sclerosis as a unique phenotype. Chest. 2010;138(6):1383-94. https://doi.org/10.1378/chest.100260

55. Szodoray P, Hajas A, Kardos L, Dezso B, Soos G, Zold E, et al. Distinct phenotypes in mixed connective tissue disease: subgroups and survival. Lupus. 2012;21(13):1412-22. https://doi.org/10.1177/0961203312456751.

56. Kawano-Dourado L, Baldi BG, Kay FU, Dias OM, Gripp TE, Gomes PS, et al. Pulmonary involvement in long term mixed connective tissue disease: functional trends and image findings after 10 years. Clin Exp Rheumatol. 2015:33(2):234-40.

57. Bodolay E, Szekanecz Z, Dévényi K, Galuska L, Csipo I, Vègh J, et al. Evaluation of interstitial lung disease in mixed connective tissue disease (MCTD). Rheumatology (Oxford). 2005;44(5):656-61. https://doi.org/10.1093/ rheumatology/keh575.

58. Malik A, Hayat G, Kalia JS, Guzman MA. Idiopathic inflammatory myopathies: clinical approach and management. Front Neurol. 2016;7:64. https://doi.org/ 10.3389/fneur.2016.00064.

59. Lundberg IE, de Visser M, Werth VP. Classification of myositis. Nat Rev Rheumatol. 2018;14(5):269-78. https://doi.org/10.1038/nrrheu.2018.41.

60. Witt LJ, Curran JJ, Strek ME. The diagnosis and treatment of Antisynthetase Syndrome. Clin Pulm Med. 2016;23(6):218-26. https://doi.org/10.1097/CPM. 0000000000000171

61. Doblough C, Garen T, Bitter H, Stjame J, Stenseth G, Grovle L, et al. Prealence and clinical characteristics of adult polymyositis and dermatomyositis; data from a large and unselected Norwegian cohort. Ann Rheum Dis. 2015;74(8):1551-6. https://doi.org/10.1136/annrheumdis-2013205127

62. Sambataro G, Sambataro D, Pignataro F, Torrisi SE, Vancheri A, Pavone M, et al. Interstitial lung disease in patients with polymyalgia Rheumatica: a case series. Respir Med Case Rep. 2018;26:126-30. https://doi.org/10.1016/j.rmcr. 2018.12.014.

63. Bartoloni E, Gonzalez-Gay MA, Scirè C, Castaneda S, Gerli R, Lopez-Longo FJ, et al. Clinical follow-up predictors of disease pattern change in anti-Jo1 positive anti-synthetase syndrome: results from a multi center, International and retrospective study. Autoimmun Rev. 2017;16(3):253-7. https://doi.org/ 10.1016/j.autrev.2017.01.008.

64. Sontheimer RD. Dermatomyositis: an overview of recent progress with enphasis on dermatologic aspects. Dermatol Clin. 2002;20(3):387-408 PMID 12170874.

65. Mukae H, Ishimoto H, Sakamoto N, Hara S, Kakugawa T, Nakayama S, et al. Clinical differences between interstitial lung disease associated with clinically amyopathic dermatomyositis and classic dermatomyositis. Chest. 2009;130(5):1341-7. https://doi.org/10.1378/chest.08-2740.

66. Sambataro G, Sambataro D, Torrisi SE, Vancheri A, Pavone M, Rosso R, et al. State of the art in interstitial pneumonia with autoimmune features: a systematic review on retrospective studies and suggestions for further avances. Eur Respir Rev. 2018;27(148). https://doi.org/10.1183/16000617. 0139-2017.

67. Lega JC, Reynaud Q, Belot A, Fabien N, Durieu I, Cottin V. Idiopathic inflammatory myopathies and the lung. Eur Respir Rev. 2015;24:216-38. https://doi.org/10.1183/16000617.00002015.

68. Moghadam-Kia S, Oddis CV, Sato S, Kuwana M, Aggarwal R. Anti-melanoma differentiation-associated gene 5 is associated with rapidly progressive lung disease and poor survival in US patients with amyopathic and myopathic dermatomyositis. Arthritis Care Res (Hoboken). 2016;68(5):689-94. https:// doi.org/10.1002/acr.22728.

69. Solomon J, Swigris JJ, Brown KK. Myositis-Related interstitial lung disease and anti-synthetase syndrome. J Bras Pneumol. 2011;37(1):100-9 PMID 21390438.

70. Waseda Y, Johkoh T, Egashira R, Sumikawa H, Saeki K, Watanabe S, et al. Antisynthetase syndrome: pulmonary computed tomography findings of adult patients with antibodies to aminoacyl-tRNA synthetases. Eur J Radiol. 2016;85(8):1421-6. https://doi.org/10.1016/j.ejrad.2016.05.012.

71. Yousem SA, Gibson K, Kaminski N, Oddis CV, Ascherman DP. The pulmonary histopathologic manifestations of the anti-Jo-1 tRNA synthetase syndrome. Mod Pathol. 2010;23(6):874-80. https://doi.org/10. 1038/modpathol.2010.65. 
72. Lega JC, Fabien N, Reynaud Q, Durieu I, Durupt S, Dutertre M, et al. The clinical phenotype associated with myositis-specific and associated autoantibodies: a meta-analysis revisiting the so-called Antisynthetase syndrome. Autoimmun Rev. 2014;13(9):883-91. https://doi.org/10.1016/ autrev.2014.03.004

73. Wang $H$, Liu T, Cai YY, Luo L, Wang M, Yang M, et al. Pulmonary hypertension in polymyositis. Clin Rheumatol. 2015;34(12):2105-12. https:// doi.org/10.1007/s10067-015-3095-7.

74. Sanges S, Yelnik CM, Sitbon O, Benveniste O, Mariampillai K, PhillipsHoulbracq M, et al. Pulmonary arterial hypertension in idiopathic inflammatory myopathies: data from the French pulmonary hypertension registry and review of the literature. Medicine (Baltimore). 2016;95(39):e4911. https://doi.org/10.1097/MD.0000000000004911.

75. Hervier B, Meyer A, Dieval C, Uzunhan Y, Devilliers H, Launay D, et al. Pulmonary hypertension in Antisynthetase syndrome: prevalence, aetiology and survival. Eur Respir J. 2013;42:1271-82. https://doi.org/10.1183/ 09031936.00156312

76. Kang EH, Lee EB, Shin KC, Im CH, Chung DH, Han SK, et al. Interstitial lung disease in patients with polymyositis, dermatomyositis and amyopathic dermatomyositis. Rheumatology (Oxford). 2005;44(10):1282-6. https://doi. org/10.1093/rheumatology/keh723.

77. Fujisawa T, Hozumi H, Kono M, Enomoto N, Hashimoto D, Nakamura Y, et al. Prognostic factors for myositis-associated interstitial lung disease. PLoS One. 2014;9(6):e98824. https://doi.org/10.1371/journal.pone.0098824.

78. Arakawa H, Yamada H, Kurihara Y, Nakajima Y, Takeda A, Fukushima Y, et al. Nonspecific interstitial pneumonia associated with polymyositis and dermatomyositis: serial high-resolution CT findings and functional correlation. Chest. 2003;123(4):109-3. https://doi.org/10.1378/chest.123.4 1096.

79. Andersson H, Aalokken TM, Gunther A, Mynarek GK, Garen T, Lund MB, et al. Pulmonary involvement in Antisynthetase syndrome: a comparative crosssectional study. J Rheumatol. 2016;43(6):1107-13. https://doi.org/10.3899/ jrheum.151067.

80. Ungprasert P, Wilton KM, Ernste FC, Kalra S, Crowson CS, Rajagopalan S, et al. Novel assessment of interstitial lung disease using the "computer-aided lung informatics for pathology Evaluatino and rating" (CALIPER) software system in idiopathic inflammatory myopathies. Lung. 2017;195(5):545-52. https://doi.org/10.1007/s00408-017-0035-0.

81. Sj B, Ibrahim GH, Holmes G, Hamburger J, Ainsworth JR. Estimating the prevalence among Caucasian women of primay Sjögren Syndrome in two general practice in Birmingham, UK. Scand J Rheumatol. 2004;33(1):39-43. https://doi.org/10.1080/030089740310004676.

82. Sambataro D, Sambataro G, Dal Bosco Y, Polosa R. Present e future of biologic drugs in primay Sjögren's syndrome. Espert Opin Biol Ther. 2017; 17(1):63-75. https://doi.org/10.1080/14712598.2017.1235698.

83. Flament T, Bigot A, Chaigne B, Henique H, Diot E, Marchand-Adam S. Pulmonary manifestations of Sjögren's Syndrome. Eur Respir Rev. 2016;25: 110-23. https://doi.org/10.1183/16000617.0011-2016.

84. Ramos-Casals M, Brito-Zeròn P, Seror R, Bootsma H, Bowman SJ, Dörner T, et al. Characterization of systemic disease in primary Sjögren's Syndrome: EULAR-SS Task Force recommendations for articular, cutaneous, pulmonary and renal involvements. Rheumatology (Oxford). 2015;54(12):2230-8. https:// doi.org/10.1093/rheumatologykev200.

85. Davidson BK, Kelly CA, Griffiths ID. Ten year follow up of pulmonary function in patients with primary Sjögren Syndrome. Ann Rheum Dis. 2000; 59(9):709-12. https://doi.org/10.1136/ard.59.9.709.

86. Kobak S, Kalkan S, Kirilmaz B, Orman M, Ercan E. Pulmonary arterial Hyprtension in patients with primary Sjögren's Syndrome. Autoimmun Dls. 2014;2014:710401. https://doi.org/10.1155/2014710401.

87. Liu Z, Yang X, Tian Z, Quian J, Wang Q, Zhao J, et al. The prognosis of pulmonary arterial hypertension associated with primary Sjögren's Syndrome: a cohort study. Lupus. 2018;27(7):1072-80. https://doi.org/10. 1177/0961203318756287.

88. Yan S, Li M, Wang H, Yang X, Zhao J, Wang Q, et al. Characteristics and risk factors of pulmonary arterial hypertension in patients with primary Sjögren Syndrome. Int J Rheum Dis. 2018;21(5):1068-75. https://doi.org/10.1111/ 1756-185X.13290.

89. Yazisiz V, Arslan G, Ozbudak IH, Turker S, Erbasan F, Avci AB, et al. Lung involvement in patients with primary Sjögren's syndrome: what are predictors? Rheumatol Int. 2010;30(10):1317-24. https://doi.org/10.1007/ s00296-009-1152-8.
90. Nilsson AM, Diaz S, Theander E, Hesselstrand R, Pitulainen E, Ekberg O, et al. Chronic obstructive pulmonary disease is common in never-smoking patients with primary Sjögren Syndrome. J Rheumatol. 2015;42(3):464-71. https://doi.org/10.3899/jrheum.140370.

91. Taouli B, Brauner MW, Mourey I, Lemouchi D, Grenier PA. Thin-section chest CT findings of primary Sjögren's Syndrome: correlation with pulmonary function. Eur Radiol. 2002;12(6):1504-11. https://doi.org/10.1007/s00330-001-1236-7.

92. Stojan G, Petri M. Epidemiology of systemic lupus erythematosus. Curr Opin Rheumatol. 2018;30:144-50.

93. Petri M, Orbai AM, Alarcòn GS, Gordon C, Merrill JT, Bruce IN, et al. Derivation and validation of the Systemic Lupus International Collaborating Clinics classification criteria for systemic lupus erythematosus. Arthr Rheum. 2012;64(8):2677-86. https://doi.org/10.1002/art.34473.

94. Lopez Velazquez M, Highland KB. Pulmonary manifestations of systemic lupus erythematosus and Sjögren Syndrome. Curr Opin Rheumatol. 2018; 30(5):449-64. https://doi.org/10.1097/BOR.0000000000000531.

95. Jawad H, MsWilliams SR, Bhalla S. Cardiopulmonary manifestations of collagen vascular disease. Curr Rheumatol Rep. 2017;19:71. https://doi.org/ 10.1007/s11926-017-0697-x.

96. Borrell H, Narvàez J, Alegre JJ, Castellvi I, Mitjavila F, Aparicio M, et al. Shrinking lung syndrome in systemic lupus erythematosus: a case series and review of the literature. Medicine (Baltimore). 2016;95(33):e4626. https:// doi.org/10.1097/MD.0000000000004626.

97. Matai SC, Danoff SK. Management of interstitial lung disease associated with connective tissue disease. BMJ. 2016;352:h6819. https://doi.org/10.1136/bmj. h6819.

98. Tselios K, Urowitz MB. Cardiovascular and pulmonary manifestations of systemic lupus erythematosus. Curr Rheumatol Rev. 2017;13(3):206-2018. https://doi.org/10.2174/1573397113666170704102444.

99. Zuily $S$, Domingues V, Suty-Selton C, Eschwège V, Bertoletti L, Chaouat A, et al. Antiphospholipid antibodies can identify lupus patients at risk of pulmonary hypertension: a systematic review and meta-analysis. Autoimmun Rev. 2017;16:576-86. https://doi.org/10.1016/j.autrev.2017.04. 003.

100. Tselios K, Giadman DD, Urowitz MB. Systemic lupus erythematosus and pulmonary arterial hypertension: links, risks, and management strategies. Open Access Rheumatol. 2016;9:1-9. https://doi.org/10.2147/OARRR.S.123549.

101. Elalouf O, Fireman E, Levartovsky D, Kaufman I, Rogovski O, Elkayam O, et al. Decreased diffusion capacity on lung function testing in asymptomatic patients with systemic lupus erythematosus does not predict future lung disease. Lupus. 2015;24(9):973-9. https://doi.org/10.1177/0961203314566633.

102. Mancuso CA, Perna M, Sargent AB, Salmon JE. A pilot study of office-based spirometry in patients with systemic lupus erythematosus. Lupus. 2012; 21(12):1343-50. https://doi.org/10.1177/0961203312456750.

103. Minai OA, Nguyen Q, Mummad S, Walker E, McCarthy K, Dweik RA. Heart rate recovery is an important predictor of outcomes in patients with connective tissue disease-associated pulmonary hypertension. Pulm Circ. 2015;5(3):565-76. https://doi.org/10.1086/682432.

104. Fischer A, Antoniou KM, Brown KK, Cadranel J, Corte TJ, du Bois RM, et al, ERS/ATS Task Force on Undifferentiated Forms of CTD-ILD. An official European Respiratory Society/American Thoracic Society research statemen: interstitial pneumonia with autoimmune features. Eur Respir J. 2015;46(4):976-87. https://doi.org/10.1183/13993003.00150-2015.

105. Zuily S, Wahl D. Pulmonary hypertension in antiphospholipid syndrome. Curr Rheumatol Rep. 2015;17(1):478. https://doi.org/10.1007/s11926-0140478-8.

106. Magro CM, Waldman WJ, Knight DA, Allen JN, Nadasdy T, Frambach GE, et al. Idiopathic pulmonary fibrosis related to endothelial injury and antiendothelial cell antibodies. Hum Immunol. 2006;67(4-5):284-97. https:// doi.org/10.1016/j.humimm.2006.02.026.

107. Miyakis S, Lockshin MD, Atsumi T, Branch DW, Brey RL, Cervera R, et al. International consensus statement on an update of the classification criteria for definite antiphospholipid syndrome (APS). J Thromb Haemost. 2006;4(2):295-306. https://doi.org/10.1111/j.1538-7836.2006. 01753.x.

108. Gomez-Puerta J, Cervera R. Diagnosis and classification of the antiphospholipid syndrome. J Autoimmun. 2014;48-49:20-5. https://doi.org/ 10.1016/j.aut.2014.01.006.

109. Woo KS, Kim KE, Kim JM, Han JY, Chung WT, Kim KH. Prevalence and clinical associations of lupus anticoagulant, anticardiolipin antibodies, anti beta2-glycoprotein I antibodies in patients with systemic lupus 
erythematosus. Korean J Lab Med. 2010;30(1):38-3. https://doi.org/10. 3343/kjlm.2010.30.1.38.

110. Torrisi SE, Vancheri A, Pavone M, Sambataro G, Palmucci S, Vancheri C. Comorbidities of IPF: How do they impact on prognosis. Pulm

Pharmacol Ther 2018; pii: S1094-5539(18)30146-9, in press doi: https:// doi.org/10.1016/j.pupt.2018.09.003

Ready to submit your research? Choose BMC and benefit from:

- fast, convenient online submission

- thorough peer review by experienced researchers in your field

- rapid publication on acceptance

- support for research data, including large and complex data types

- gold Open Access which fosters wider collaboration and increased citations

- maximum visibility for your research: over $100 \mathrm{M}$ website views per year

At $\mathrm{BMC}$, research is always in progress.

Learn more biomedcentral.com/submissions 